\title{
HUGH FORBES, SOLDIER OF FORTUNE
}

\author{
By Lida L. Greene \\ Librarian of lowa State Historical Library
}

Try asking the people of Tabor, Iowa, if they remember Hugh Forbes. Most of them would look puzzled and some man would be almost certain to say, "Hey! Isn't that the beanpole of a kid who plays center for the Sidney ball club?" Not that Taborites should be expected to remember Forbes. $\mathrm{He}$ was a one-time visitor a 110 years ago. That was when Tabor was an outpost of the New England conscience facing west toward the Missouri and a trail that led to bleeding Kansas.

We were reminded of Hugh Forbes recently when the study, Hugh Forbes, His Life and Writings, by Fred McFarland of the University of Colorado, arrived in the mail. Fred has been on the trail of Forbes since his undergraduate years. A series of letters written to the Historical Library are eloquent testimony to his continuing search for the key to the understanding of this strange, little-known soldier of fortune. In his most recent paper, Forbes appears to be emerging as one of the imponderables, the what-ifs of the John Brown drama. What if Forbes had been won to the anti-slavery, what if he had trained an irregular army, what if . . .

Hugh Forbes was English, an engineer and a linguist, when he went to Italy to join Garibaldi in his fight for freedom. After the defeat of the partisans in 1849, Forbes fled to the United States. In the years between Italy and Tabor, he supported himself by translations for newspapers and by teaching fencing and horsemanship.

When John Brown went to New York in 1857 to raise money for his anti-slavery ventures, he was also searching for military advisers. Acquaintances of Forbes and Brown brought them together. Forbes was given $\$ 600$ for six months work, part of the money to be spent for translation and publication of a manual on guerilla warfare.

Forbes did not arrive at Tabor until August, 1857. The volunteer army he was to have trained was non-existent. There was only John Brown and his son, Owen, to study gunnery and the manual of arms. It is said that Brown discussed with his 
adviser the proposed strategy for the assault on the Harper's Ferry Arsenal and that Forbes suggested major changes.

Upon his return to the east, Forbes found himself short of funds. In early winter he began a series of abusive and, finally, threatening letters to John Brown and friends of his cause. Brown, he alleged, had defrauded him out of six months' pay. When no money was forthcoming, he began to spread the story of the Brown plot in the nation's capital.

Supporters of Brown persuaded him, albeit with the greatest reluctance, to postpone the arsenal attack for a year. In Washington, the Forbes allegations began to be dismissed as a fanatic rumor. The soldier of fortune himself became an almost forgotten man. With the resurgence of the freedom movement in southern Europe, Forbes returned to fight with Garibaldi in the Sicily campaign. On Oct. 18, 1859, John Osawattamie Brown carried the torch of his anger into Harper's Ferry, Va.

Naturally we hope the Hugh Forbes story will incite you to follow the John Brown trail in Iowa this summer. Begin now by marking the sites on your map: Quaker Springdale in Cedar County and west to Grinnell, Lewis, Tabor. The aura of the Brown drama remains at Tabor. Look for the red brick Congregational church, the low frame house of Father Todd, the park with a plaque on a boulder that reads:

\section{JOHN BROWN'S CAMP GROUND 1858-1859}

There is still time to acquire a reading background on the Brown story. Your own public library will have a book or two and, of course, the latch string is always out at the Iowa Historical Library. We have John B row n biographies from Brown's own record to Villard and Webb. The new study, Hugh Forbes: His Life and Writings by Fred McFarland will be on the shelves by the day you arrive. One volume you must be sure to see is a small, red-backed, battered book dated 1857 and titled Forbes Volunteer's Manual, Vol. I. The hand written inscription inside will give you pause. This is the Manual used by the author at Tabor, Iowa, in 1857-summer and autumn, in drilling John Brown and his son, Owen ... From Col. Hugh Forbes at Davenport. Geo. F. Magoun 1/57 (Aug.) 
Copyright of Annals of Iowa is the property of State of Iowa, by \& through the State Historical Society of Iowa and its content may not be copied or emailed to multiple sites or posted to a listserv without the copyright holder's express written permission. However, users may print, download, or email articles for individual use. 